ORIGINAL ARTICLE

AFRICAN JOURNAL OF CLINICAL AND EXPERIMENTAL MICROBIOLOGY AJCEM/201097/21124

COPYRIGHT 2011

AFR. J. CLN. EXPER. MICROBIOL 12(3): 1119-123
SEPTEMBER $2011 \quad$ ISBN 1595-689X VOL 12(3)

-http://www.ajol.info/journals/ajcem doi: 10.4314/ajcem.v12i3.6

\title{
TOXOPLASMA ANTIBODIES AMONGST HIV/AIDS PATIENTS ATTENDING THE UNIVERSITY TEACHING HOSPITAL YAOUNDÉ, IN CAMEROON
}

Jules C.N. Assob', Anna L. Njunda², Dickson S. Nsagha, Henri L. Kamga ${ }^{2}$, Patrick E. Weledji', V. B. Che².

\begin{abstract}
${ }^{1}$ Department of Biomedical Sciences, Faculty of Health Sciences, University of Buea, Cameroon. P.O.Box: 63 Buea Cameroon. ${ }^{2}$ Department of Medical Laboratory Sciences, Faculty of Health Sciences, University of Buea, Cameroon. P.O.Box: 63 Buea Cameroon. P.O.Box: 63 Buea Cameroon; ${ }^{3}$ Department of Public Health and Hygiene, Faculty of Health Sciences, University of Buea, Cameroon. P.O.Box: 63 Buea Cameroon; ${ }^{4}$ Department of Clinical Sciences, Faculty of Health Sciences, University of Buea; Cameroon. P.O.Box: 63 Buea Cameroon.
\end{abstract}

Correspondence: Dr Jules Clement Nguedia Assob, Programme in Medicine, Department of Biomedical Sciences, Faculty of Health Sciences, University of Buea. Email: jcassob@hotmail.com, Tel. 23799629452 P.O.Box: 63 Buea, South West Region, Cameroon.

\section{ABSTRACT}

Toxoplasmosis is caused by an obligatory intracellular protozoon. It causes a wide range of diseases with toxoplasma encephalitis commonly encountered in HIV/AIDS patients. This work was carried out to determine the seroprevalence of toxoplasma antibodies (IgM and IgG) in HIV/AIDS patients attending the Yaoundé University Teaching Hospital (UTH) in Cameroon. Sera were collected from 133 HIV/AIDS patients at the out-patient department and the ELISA technique was employed serologically to determine toxoplasma antibodies. Of the 133 patients $83(62.4 \%)$ were females and $59(37.6 \%)$ were males; ninety three $(69.9 \%)$ were positive for toxoplasma antibodies. Fourteen $(10.8 \%)$ of the 93 of seropositive patients presented with both IgG and IgM-antibodies in their sera while fifty six $(42.1 \%)$ and $8(6.0 \%)$ were only sero-positive for toxoplasma IgG or IgM-antibody respectively

This rate of infection was not dependent on the patient's sex or age $\left(X^{2}=11.49, P>0.05\right)$. The data provides enough evidence to conclude that $64.7 \%$ of the positive cases were due to reactivated infection.

Key words: Toxoplasmosis, HIV/AIDS, Pregnancy, Risk factors, Prevalence, Yaounde, Cameroon.

\section{INTRODUCTION}

Toxoplasmosis is caused by an obligatory intracellular protozoan; Toxoplasma gondii of worldwide distribution (1). It has gradually evolved over the pass decades to be among the most common opportunistic diseases in HIV/AIDS in developing countries (2). The prevalence of seropositivity for antibodies against Toxoplasma gondii has been estimated at 3\% in Western Europe and $67 \%$ to $90 \%$ in tropical countries. Transmission is mainly by ingestion of tissue cysts in raw and undercooked meat, exposure to oocysts in contaminated vegetable or contact with faeces of a felid (2).The development of a cell-mediated immunity after an acute infection results in the control of the disease, but not the eradication of the infection. The issuing of a chronic or latent phase of infection is characterized by the presence of the persistence form (cysts) of the organism in tissues (skeletal muscles, heart and brain). An infected individual who develops a defective cell-mediated immunity is at risk of reactivated infection $(1,2,3)$. In Cameroon such data are scarce, and information used is usually from developed countries. This study was therefore carried out to determine the sero-prevalence of $T$. gondii among HIV/AIDS patients to help guide health care providers initiating treatment.

\section{MATERIALS AND METHODS}

Study Area
This study was carried out at the University Teaching Hospital in Yaoundé (UTHY), located in the Central Region of Cameroon. Yaoundé is the political capital of Cameroon; with a cosmopolitan population of $3,098,044(\sim 16 \%)$ inhabitants of a total population of $19,406,100$ peoples. The town therefore attracts people from all regions of the country. The University Teaching Hospital (UTH) Yaoundé, where the study was conducted is one of the 4 reference hospitals in Yaoundé, which handles the diagnosis, treatment and management of many diseases including toxoplasmosis and HIV/ AIDS.

\section{Study Population and Sample Collection}

This study was carried out from February 2010 to May, 2010. We used volunteer patients already diagnosed and confirmed to be HIV positive. Written informed consent forms were distributed to the participants one week prior to the beginning of the samples collection. Only HIV positive volunteers who returned their informed consent forms duly signed were recruited irrespective of their gender or clinical state of the disease. All age groups were recruited in the study. We collected at least $2 \mathrm{ml}$ of venous blood from each patient. The samples were then centrifuged after the blood had clotted to obtain serum that was collected into serum-tubes and stored in the freezer for at most three days. Collection was done every week day 
from 8 am to $1 \mathrm{pm}$ and sample processing was done twice a week or once a batch reaches 9 samples Sero-analysis

The ELISA technique was employed to estimate the levels of toxoplasma IgG and IgM antibodies in patients' sera collected. Toxoplasma gondii antibody enzyme ELISA kit is a solid phase enzyme-linked immune-sorbent assay (ELISA). The ELISA method relies basically on the formation of an antigenantibody complex, on which an enzyme conjugate binds and then reacts with a substrate that is detectable by the ELISA machine. Therefore if a patient has toxoplasma antibodies, they will bind on the antigens coated on the walls of the microwells. The intensity of the reaction between a substrate and the conjugate enzyme is reflective of the degree of the formation of the antigen-antibody complex and hence, estimates qualitative and quantitative toxoplasma antibodies in the patient's serum. The procedure was carried out as described by Calderaro et al.(4)

\section{Reporting Results}

The ELISA gives results in terms of absorbance (optic density). The values of $\operatorname{IgM}$ and $\operatorname{IgG}$ are calculated using a calibration curve converted in the standard international units $/ \mathrm{ml}(\mathrm{IU} / \mathrm{ml})$.

For IgG values $>73 \mathrm{IU} / \mathrm{ml}$ positive

$$
=60 \text { to } 73 \mathrm{IU} / \mathrm{ml}
$$

equivocal

For IgM values $>37 \mathrm{IU} / \mathrm{ml}$ positive

$$
<60 \mathrm{IU} / \mathrm{ml} \text { negative }
$$

$$
=30-37 \mathrm{IU} / \mathrm{ml} \text { Equivocal }
$$

$$
<30 \mathrm{IU} / \mathrm{ml} \text { negative }
$$

\section{Statistical Analyses}

The Chi-Square test was used to test the association between patient characteristics of the sample population and Toxoplasma gondii sero-positivity data. A confidence level of $95 \%$ was chosen (Pvalue $=0.05)$ and values of chi-square computed using Yates correction. collected.

\section{RESULTS}

A total of 133 immune compromised (HIV/AIDS) patients participated in this sero-survey. Ninety three $(69.9 \%)$ of the patients were sero-positive for toxoplasma-antibodies and $40(29.1 \%)$ were seronegative. Fourteen $(10.8 \%)$ of the $93(69.9 \%)$ of the sero-positive patients presented with both $\mathrm{IgG}$ and IgM-antibodies in their sera. Fifty six $(42.1 \%)$ and 8 $(6.0 \%)$ were only sero-positive for toxoplasma IgG or IgM-antibodies respectively. Seven $(5.2 \%)$ were sero-positive for IgG-antibodies and ambiguous in IgM titers, and 2 (1.5\%) were only sero-positive for IgM-antibodies and ambiguous for toxoplasma IgG-antibodies. Three (2.3\%) were serologically ambiguous for both toxoplasma IgG- and IgM titers. Two (1.5\%) were serologically ambiguous for toxoplasma IgG-antibodies and negative for IgM while $1(0.7 \%)$ was ambiguous for IgM and negative for IgG antibodies (Table 1).

From the 93 positive patient samples analyzed, 119 positive titers where obtained. $77(64.7 \%)$ and 7 $(5.9 \%)$ IgG titers were fully established and ambiguous respectively, and $24(20.2 \%)$ and 11 (9.2\%) IgM titers were fully established and ambiguous respectively. The data provided a $\mathrm{P}$ value $>0.5$ (table2).

Of the $133 \mathrm{HIV} /$ AIDS patients that participated in the human sero-survey, $83(62.4 \%)$ were females and $50(37.6 \%)$ were males. Fifty nine $(71.1 \%)$ of the $83(62.4 \%)$ females and $34(68.0)$ of the $50(37.6 \%)$ males were sero-positive for Toxoplasmaantibodies (Table 3).

The age of the studied population ranged from 17 to 55 years of age. The data was categorized into 8 ranges with a class width of 4 . The modal class was $26-30$ years of age, with a frequency of $39(29.3 \%)$

\begin{tabular}{|c|c|c|c|c|c|}
\hline & & \multicolumn{4}{|c|}{ TOXOPLASMA IgG ANTIBODIES } \\
\hline & & $\begin{array}{l}\text { Positive } \\
\text { No }(\%)\end{array}$ & $\begin{array}{l}\text { Equivocal } \\
\text { No }(\%)\end{array}$ & $\begin{array}{l}\text { Negative } \\
\text { No }(\%)\end{array}$ & $\begin{array}{l}\text { Total } \\
\text { No (\%) }\end{array}$ \\
\hline \multirow{4}{*}{$\begin{array}{l}\text { Toxoplasma } \\
\text { IgM } \\
\text { Antibo dies }\end{array}$} & Positive & $14(10.52)$ & $2(1.50)$ & $8(6.01)$ & $24(18.04)$ \\
\hline & Equivocal & $7(5.26)$ & $3(2.25)$ & $1(0.75)$ & $11(8.27)$ \\
\hline & Negative & $56(42.10)$ & $2(1.50)$ & 40 (30.07) & $98(73.78)$ \\
\hline & Total & $77(57.89)$ & $7(5.26)$ & $49(36.84)$ & $133(100.00)$ \\
\hline & & & & & \\
\hline
\end{tabular}
and an observed sero-positivity frequency of 32 $(24.1 \%)(\mathrm{P}<0.05)$ (Table 4).

\section{TABLE 1: TOXOPLASMA ANTIBODIES IN HIV/AIDS PATIENTS AT THE UNIVERSITY HOSPITAL YAOUNDÉ}


TABLE 2: DISCRIMINATIVE DISTRIBUTION OF TOXOPLASMA IGM AND IGG TITERS IN HIV/AIDS PATIENTS

\begin{tabular}{|c|c|c|c|}
\hline & $\begin{array}{l}\text { Established } \\
\text { positive } \\
\text { No }(\%)\end{array}$ & $\begin{array}{l}\text { Equivoque } \\
\text { No }(\%)\end{array}$ & $\begin{array}{l}\text { Total } \\
\text { No }(\%)\end{array}$ \\
\hline IgG & 77 (64.70) & $7(5.88)$ & $84(70.58)$ \\
\hline IgM & 24 (20.16) & $11(9.24)$ & $35(29.41)$ \\
\hline Total & $101(84.87)$ & $18(15.12)$ & $119(100)$ \\
\hline
\end{tabular}

TABLE 3: DISTRIBUTION OF OXOPLASMA SERO-POSITIVITY ACCORDING TO SEX

\begin{tabular}{|c|c|c|c|}
\hline Sex & $\begin{array}{l}\text { Positivity } \\
\text { No }(\%)\end{array}$ & $\begin{array}{l}\text { Negative } \\
\text { No }(\%)\end{array}$ & $\begin{array}{l}\text { Total } \\
\text { No }(\%)\end{array}$ \\
\hline Male & $34(25.56)$ & $16(12.03)$ & $50(37.59)$ \\
\hline Female & $59(44.36)$ & $24(18.04)$ & $83(62.40)$ \\
\hline Total & $93(69.92)$ & $40(30.07)$ & $\begin{array}{l}133 \\
(100.00)\end{array}$ \\
\hline
\end{tabular}

Df $=1 \quad$ P-value $=0.05 \quad X^{2}=0.037$

\section{DISCUSSION}

The T. gondii seroprevalence estimated for human population varies greatly among different countries, among different geographical areas within the same country, and among different ethnic groups living in

the same area (5). In this study the prevalence of

Toxoplasma gondii antibodies in an HIV-positive population at the UTHC Yaoundé was found to be $69.9 \%$. This figure does not differ much from that obtained in other African countries : $75.4 \%$ in Nigeria

(6), $60 \%$ from AIDS patients in Cote d'Ivoire (7),

$58.4 \%$ in Tunisia (8), 53.6\% in Benin (9), $40.2 \%$ in

Senegal (10), 34.1\% from pregnant women in Sudan (11), and $28.5 \%$ in HIV positive women in Benin (5) and confirms the geographical variation. The absence of prevention strategies on serious risks of acquiring primary infection during pregnancy in these countries may account for these important prevalence values.

In Cameroon, a similar study carried in 1992 (12), revealed a toxoplasmosis sero-prevalence of $77.1 \%$ in pregnant women. The difference in the seroprevalence of toxoplasmosis obtained in this study can be associated to the fact that in some HIV/AIDS patients, the failing immune system may not produce detectable amounts of antibodies, hence may account for a low sero-prevalence in the sample. Recently, highly active antiretroviral therapy (HAART) against HIV infection has been advocated for improving the
TABLE 4: DISTRIBUTION OF TOXOPLASMA SERO-POSITIVITY ACCORDING TO VARIOUS AGE RANGES

\begin{tabular}{|c|c|c|c|}
\hline Class (age) & $\begin{array}{l}\text { Positive } \\
\text { No }(\%)\end{array}$ & $\begin{array}{l}\text { Negative } \\
\text { No }(\%)\end{array}$ & $\begin{array}{l}\text { Total } \\
\text { No }(\%) \\
\end{array}$ \\
\hline $16-20$ & $1(0.75)$ & $4(3.01)$ & $5(3.76)$ \\
\hline $21-25$ & 23 (17.29) & 14(10.53) & $37(27.82)$ \\
\hline $26-30$ & $32(24.06)$ & $7(5.26)$ & $39(29.32)$ \\
\hline $31-35$ & $17(12.78)$ & $6(4.51)()$ & $23(17.29)$ \\
\hline $36-40$ & 13(9.77) & $2(1.50)$ & 15(11.28) \\
\hline $41-45$ & $5(3.76)$ & $3(2.26)$ & $8(6.02)$ \\
\hline $46-50$ & $1(0.75)$ & $4(3.01)$ & $5(3.76)$ \\
\hline $51-55$ & $1(0.75)$ & $0(0.00)$ & $1(0.75)$ \\
\hline Total & $93(69.92)$ & $40(30.08)$ & $133(100.00)$ \\
\hline
\end{tabular}

immune status of patients thus reducing the incidence of opportunistic infections (13); The studied population was on antiretroviral treatment regimens thank to the implementation of a national decentralization programme for HIV care in 2006 that led to existing health infrastructures being overwhelmed by a huge demand for treatment (14). This could explain the fact that most patients with antibodies presented with no clinical symptoms of the disease. However non-adherence remains a major concern as the antiretroviral treatment (ART) programs scale up and as more patients are expected to remain on this life-long therapy, this necessitates the need for the development of additional interventions to maintain optimal adherence to ART and consequently to reduce patients' vulnerability to opportunistic infections (15). The particular clonal lineage may be different compared to the rest of the continent and the world. However, studies by Lindström et al. (16) described the genotype distribution in Uganda to be very similar to that in Europe, where type II allele of SAG2-locus was the most common. As compared to other areas (Uganda where the prevalence was $80 \%$ ), this area presents a better socio-economic condition, rapid urbanization, improved access to potable water and sanitation facilities though constant breakdowns from time to 121 
time, continued awareness around good hygiene, education and rare exposure to stray cats are characteristics of the Yaoundé region. The global variation in prevalence may also be attributed to different cultural habits. The high prevalence has been linked to the practice of Buddhism in Thailand which has significantly led to the increase in amount of stray cats, hence increased possibility of human infection (13). In Mexico and Brazil, cats are fed with raw viscera and leftover, increasing the chance of human infection (17). A $64.7 \%$ IgG to $20.2 \%$ IgM titer provide enough statistical evidence to conclude that there is a $95 \%$ possibility of any random patient of presenting with at least a high IgG titer for toxoplasma antibodies. This can be surely attached to their failing immune system increasing the patient's vulnerability and the fact that IgG-antibodies last longer than IgM-antibodies. It is therefore possible most of the toxoplasmosis cases in HIV/AIDS are due to a reactivated infection (18). A $3 / 5$ ratio of male to females $(p>0.05)$ did not provide enough statistic evidence that positivity of toxoplasma antibodies is not sex dependent. Hence, any random gender with equal risk behaviors can be positive or negative. The modal class in this study was within the range of 26 to

\section{REFERENCES}

1 Tenter A. M., Heckeroth A. R., Weiss L. M. Toxoplasma gondii: from animals to humans. Intern. J. Parasitol. 2000; 30: 1217-1258.

2. Montoya J. G., Rosso F. Diagnosis and management of toxoplasmosis. Clin Perinatol. 2000; 32: 705-726.

3. Luft B. J., Remington J. S. Toxoplasmic encephalitis in AIDS. Cli Infect Dis. 1992; 15: 211-222.

4. Calderaro A, Piccolo G, Peruzzi S, Gorrini C, Chezzi C and Dettori G. Evaluation of Toxoplasma gondii Immunoglobulin G (IgG) and IgM Assays Incorporating the New Vidia Analyzer System. Clin. Vacc. Immunol, July 2008, p. 1076-1079, Vol. 15, No. 7

5. Simpore J., Savadogo A., Ilboudo D., Nadambega M. C., Esposito M., Yara J., Pignatelli S., Pietra V., Musumeci S. Toxoplasma gondii, HCV, and HBV seroprevalence and co-infection among HIVpositive and - negative pregnant women in Burkina Faso. J Med Virol. 2006; 78:730-733.

6. Onadeko M. O., Joynson D. H., Payne R. A, Francis J. The prevalence of Toxoplasma antibodies in pregnant Nigerian women and the occurrence of stillbirth and congenital
30 years of age and could be due to the fact that this age group constitute the most active part of a population and are therefore exposed to many risk factors. However, the statistics did not provide enough evidence to incriminate a particular HIV/AIDS age group to positivity with toxoplasma antibodies.

\section{CONCLUSION}

This human sero-survey has shown the presence of toxoplasmosis amongst HIV/AIDS patients at UTHCY, with a prevalence of $69.9 \%$. This infection rate does not depend on the patient's sex or age. The data also provide enough evidence to conclude that $64.7 \%$ of the positive cases are due to reactivated infections. Pregnant women and immunecompromised patients should be screened for previous Toxoplasma gondii exposure to ensure adequate clinical and individual precautions to prevent an acute or a reactivated infection.

\section{ACKONOLEDGEMENTS}

The authors wish to thank all the laboratory personnel of the University Teaching Hospital of Yaoundé for their technical support.

7. Adou-Bryn K. D, Ouhon J., Nemer J., Yapo C. G., Assoumou A. Serological survey of acquired toxoplasmosis in women of childbearing age in Yopougon (Abidjan, Cote d'Ivoire). Bull. Soc. Pathol. Exot. 2004; 97:345-348.

8. Bouratbine A., Siala E., Chahed M. K., Aoun K., Ben Ismail R. Seroepidemiologic profile of toxoplasmosis in Northern Tunisia. Parasite Immunol. 2001; 8:61-66.

9. Rodier M. H., Berthonneau J., Bourgoin A., Giraudeau G., Agius G., Burucoa C., Kekpazo A., Jacquemin J. L. Seroprevalences of toxoplasma, malaria, rubella, cytomegalovirus, HIV and treponemal infections among pregnant women in Cotonou. Repub. Benin. Acta Trop. 1995; 59:271-277.

10. Faye O., Leye A., Dieng Y., Richard-Lenoble D., Diallo S. Toxoplasmosis in Dakar. Seroepidemiologic sampling of 353 women of reproductive age. Bull. Soc. Pathol. Exot. 1998; 91:249-250.11. Elnahas A., Gerais A. S, Elbashir M.I, Eldien E. S., Adam I. Toxoplasmosis in pregnant Sudanese women. Saudi. Med. J. 2003; 24: 868-870. 122 
12. Ndumbe P. M., Andela A., NkemnkengAsong J., Watonsi E., Nyambi P. Prevalence of infections affecting the child among pregnant women in Yaoundé, Cameroon. Med. Microbiol. Immunol. 1992; 181:127-130.

13. Sukthana Y., Chintana T., Supathanapong W., Siripanth C., Lekkla A., Chiabchalard R. Prevalence of toxoplasmosis in Selected Populations in Thailand. J Trop Med Parasitol 2000;23:53-58

14. $\mathrm{MOH}$ (Ministry of Public Health). National strategy plan to fight against HIV/AIDS. National Committee to FightAIDS, Cameroon. 2006-2010,Yaounde, Cameroon. 2009

15. Kamga H. L. F., Assob J. C. N., Njunda A. L, Nsagha D. S., Nde Fon P., Atanga M. B. S., Weledji P., Achidi E. A. Puinta D. P. The kidney function trends in HIV/AIDS patients. Lambert Academic Publishing, Germany. 2011

16. Lindström I., Kaddu-Mulindwa D., Kironde F., Lindh J. Prevalence of latent and reactivated Toxoplasma gondii parasites in HIV-patients from Uganda. Acta Trop. 2006; 100: 218-222.

17. Sukthana, Y. Toxoplasmosis: beyond animals to humans. Trends Parasitol., 2006; 22:137142

18. Rougemont M., Stoll B. E, Elia N., and Ngang P. Antiretroviral treatment and its determinants in sub-Saharan Africa: a prospective study at the Yaounde Central Hospital, Cameroon. AIDS Res. Ther. 2009; $6: 21$. 